\title{
The Implementation of Blended Learning Using English Discoveries for English Intensive Program at UINSA: Teachers' and Students' Perspectives
}

\author{
Suparto \\ English Department-Faculty of Art and Humanities, \\ Universitas Islam Negeri Surabaya \\ Indonesia \\ Olivia Indah Purwanti \\ English Language Education Department, \\ Universitas Islam Negeri Surabaya \\ Indonesia
}

\author{
Mawadah Insyaa Sakinah \\ English Language Education Department, \\ Universitas Islam Negeri Surabaya \\ Indonesia \\ Nur Anisah \\ English Language Education Department, \\ Universitas Islam Negeri Surabaya \\ Indonesia
}

\begin{abstract}
English Discoveries is the something new that used in english intesive program at Uin Sunan Ampel Surabaya. This invites many opinions from several teachers and students who use it. Because of that, the aim of this research is to identify the teacher and students perception when they are using English Discoveries in Intensive program. This research used qualitative to collected the data in perception of students and teachers. To support the data, the collecting data technique using interview to the teachers and students in every faculties in UIN Sunan Ampel Surabaya. According to the finding of the interviewed the participants about the teachers and students perception using English discoveries the researcher found conclude that English Discoveries can help the English learning process in Intensive Program more practical and efficient. Nonetheless there some obstacles when using English Discoveries.
\end{abstract}

\section{Keywords: English Discoveries, perception}

\section{INTRODUCTION}

In this $21^{\text {st }}$ Century, technology becomes the one of important thing in Human life and developing in Education field. One of the uses of technology in Education is the existence of Online Learning. Online learning is a type of technology-based learning where the learning process takes place online by utilizing technology and the internet as media. The use of online learning in this era is one of the learning models and strategies demanded by teachers and school institutions. According to a study from Tanveer, Asma, Munazza (2015) the use of online learning also improves students' and teachers' motivation in the learning environment. There are various forms of online learning, one that has been massively adapted in teaching learning process is Blended Learning.

Blended Learning is an approach of face-to-face learning systems with online learning that can be used by anyone, anywhere and anytime. According to (J.Poon, 2014) Blended learning is the activity of teaching-learning with integrating the technology in the conventional learning or combining face to face learning with the online learning. Learning in blended learning makes students able to review the content they have learned in the class on the websites or Learning Management System (LMS) (Yilmaz,Orhan, 2010) and allows to minimizing the teaching-learning process in the classroom.

The use of blended learning has also begun to be applied to several schools and universities in Indonesia. One of the universities that has recently implemented this learning strategy is Islamic University of Sunan Ampel Surabaya or UINSA. UINSA has implemented this strategy in their intensive English program for the students in the first and second semester since 2018. Formerly, the intensive English language program at UINSA implemented the traditional methods with face to face meetings and used books as media in providing materials. However, this program has changed its strategy into Blended Learning. 
The main purpose of replacing the previous strategy into Blended Learning is to prepare the students to take the Test of English for International Communication or TOEIC and to prepare the students' skilled of English in their future job latter, it is different with the previous strategy that only focused on prepare the students to get high score in Test of English as a foreign language or TOEFL. Furthermore, according to the coordinator of English Program at UINSA Roudhatul Jannah (2018) the implementation of Blended Learning is to create learning English process in the Intensive program more efficient for both students and teachers because face to face meeting is not too often and also make students accustom for using technology in the learning process. In applying the Blended learning strategy, UINSA is using English Discoveries as the learning management system to provide the materials and the assignments.

Besides that, there several studies which talked about the implementation of Blended learning for example like the study from (Nanik Handayani 2019) examined about the students' achievements in speaking skill through the implementation of the blended learning approach one of Junior High School in Maluku. To collected the data, the researcher took the sample by Experimental study and involved one class of the population without a control group and their pretest and post tense. The result of this study showed that the blended learning approach has contribution about $11 \%$ in improving the students' speaking skill achievement. The researcher also suggested that the students to active and controlling their participation in joining the learning process. One of the learning management systems that can be used to Implement Blended Learning approach is English Discoveries.

English Discoveries is one of Learning management systems for learning English. It has been widely used to learning and teaching English and suitable for all levels for the example in education, employees, institution, etc. This learning management system provides more than one thousand materials for helping students to improve their English competences for the example listening, reading, grammar, vocabularies, etc. English discoveries supported by several features such as teacher management system, authoring tool, ED advanced speech recognition and automated writing evaluation. Moreover, there are also some training media like discussion online forum, online magazine, games, talking idiom, and grammar book. So, English discoveries has some advantages in learning and teaching English. The first advantage is effective to motivate the students in their learning English process. The second advantage is making their learning easier to access in everywhere or every time (ITC-Indonesia ,2016). The last advantage by (C. Fearon, S. Starr and H. McLaughlin, 2011)who stated that Blended learning can be interact students and teachers in face to face system and after the class hours using technology tools.

The previous study from (Pham, Dakich, Thalathoti, and Dang, 2012) examined the use of English Discoveries can attach the students' attention and makes engagement between the learner and instructor. Moreover, the use of English Discoveries can develop the understanding of the students in their material and their task (Benavides, 2016) because by using this learning management system, the students may control their learning process by themselves. For example, in students' speaking activity they may record and compare their performance to the original exchange of the native speaker. Above all, it can be concluded that English Discoveries is the interesting media for teaching English. By using the English Discoveries, the students can more enjoy of their learning English and this learning management system also could be controlled by them.

Besides that, according to ITC-Indonesia (2016) the Implementation of English Discoveries at UINSA especially in English Intensive Program. The English Intensive Program classes which implement the blended learning as teachinglearning approach is called as Flipped Classroom. Thus, it is generating the problem of the implementation English Discoveries at UINSA. The aim of this study is wants to explore the students' and teacher's perceptions about the use of English Discoveries as the media for the Implementation of Blended Learning approach in Flipped classroom at UINSA. Then it gives many benefits or even give the loss for the students. In addition, this is new approach which has never been done before. It is of course generating some problems, what are students' and teachers' challenges and how they overcome or respond for this. These need to be examined and that is why this research was born.

\section{RESEARCH QUESTIONS}

I. What are the students' and teachers'

perception of the use of English discoveries in

English intensive program at UIN SUNAN

\section{AMPEL SURABAYA?}

This Research Question includes of:

\section{- The Definition of English Discoveries}

- The Challenges that they faced

- How they implement it

- $\quad$ The benefits from English Discoveries

\section{Blended Learning}

Blended learning is a learning strategy which combines face-to-face learning directly and online. Blended learning is one of the new learning strategies that provide many benefits for students, as well as a form of information and communication technology support towards a new learning mode (Graham, 2006). Kanuka, Brooks and Saranchuck (2009) described that Blended learning as a mode of teaching that eliminates time, place, and situational barriers, whilst enabling high quality interactions between teachers and students. 
By using blended learning teacher can easily to manage the learning process, because blended learning it is not only teaching and learning process in the classroom, but also teaching and learning by using online. According to Murphy (2002) established that there are some advantages of blended learning, for the example to reach the learning objectives, change the rules of teaching and learning process from teacher center into students' center, for balancing students' independence and motivate students to discipline themselves in learning process.

In the $21^{\text {st }}$ century, teachers should be able to apply technology in learning process, for example, applying the blended learning method into the learning process. The purpose is to make the teaching and learning process not monotonous, but to be more effective, varied, and also be able to motivate students in learning process. So, the implementation of blended learning method is easy, because, the teacher can reduce the learning time in the classroom. So, learning process will be more effective and efficient.

A number of studies has conducted some researches related to blended learning, one of them is the study from Lyn Jeffrey, L. M., Milne, J., Suddaby. G., \& Higgins, A. (2014) examined about what teachers actually do in blended learning, and signals steps that teachers and their institutions might take to build on the opportunities presented by blended learning. They used qualitative research and interviewed Nine tertiary teachers from two state universities, teaching blended learning courses. The sample included three females and six males, aged between 36 and 60experienced teachers with more than 5 years' tertiary level teaching. All but one teacher had previous experience of teaching in a blended context. This study concluded that most of teachers argued that the teacher should be the central actor, with technology playing a minor support role.

Another study, from Sudaarman (2018) established that by using blended learning the teaching learning process is better rather than faceto-face in the classroom. Conducted to the study which focus on the students with Self-Regulated Learning. This study conducted in Quantitative research and involved 104 participants from Malang University. The result of this study, showed that the students who have high Self-regulated Learning when using blended learning they can the students can learn about the concept and procedure better than the students with lower Self-Regulated Learning. The aimed of this study is to examine the effect of the blended learning toward the learning concept and the statistical produce. Using blended learning as the strategy especially to teach English, it means that teachers should be able to utilizing learning management system to provide materials in online learning. The one of recommended learning management system that usually used in Blended Learning is English Discoveries.

\section{Flipped Classroom}

Flipped classroom is also known as a student-centered approach to learning where the students are more active than the instructor in the classroom activity. In this case, the instructor acts as a facilitator to motivate, guide, and give feedback on students' performance (Sams \& Bergmann, 2012).Applying flipped classroom approach also contributes to better understanding of technology use in teaching and learning activities; students will use various technology media in learning activities independently, while the lecturer will use various technology media in their teaching practices (Zainuddin \& Attaran, 2015).In implementing flipped classroom, remembering and understanding as the lowest levels of cognitive domain are practiced outside the class hour (Krathwohl \& Anderson, 2010).

Flipped classroom has already used in several schools and high institution in Indonesia. One of them is Islamic University of Sunan Ampel Surabaya or Uinsa. They use this approach in their English Intensive Program and combine it with Blended Learning approach. The use of flipped classroom approach in English Intensive program aims to designing classes to become students' centers where learning does not focus on teacher explanations but provides opportunities for students to be active in the learning process. The teachers' jobs here are only for their facilitator, and guide them to learn by themselves. Therefore, students are given facilities in the form of learning management systems as their guidelines which are provide the material, task and also assignments for them.

\section{English Discoveries}

English discoveries are one of Learning Management System for learning English by using blended learning. It means that, English Discoveries combines online learning with face-to-face methods. Besides that, English Discoveries Online (EDO) is a computer-assisted, interactive platform for English language learning which targets language skills, such as listening, reading, speaking, writing, grammar, and vocabulary, using a variety of topicbased materials covering authentic genres (adapted from ICT English Proficiency Training Plan of Edu power and Edu soft).

There are some features in English Discoveries. For the example, discussion time forum, online magazine, games, talking idiom, and grammar book. First, discussion time forum. There 
is one of the features that the ED users used for doing discussion like mailing list. Second, online magazine which provide some articles. Those articles are available based on the level of ED's users. So, they can easier to read those articles. Third, games. In these games, the ED's users can enlarge their new vocabularies. Fourth, talking idiom. There is an interesting way to learn English idioms and their meanings and examples of use in everyday conversation. The last, grammar book. Explain about some grammar and how to use it in the correct form.

English discoveries have some advantages in learning and teaching English. First, is effective. It means that make the students motivate when the learning process are combined. Second, is faster and flexible. There are several studies about the use of English Discoveries, one of them is the study from Sherilyn and Yolanda (2017) that conducted the study about the assessment and evaluation of English Discoveries Online, and focused and is the implementation of this learning management system gives the improvement in students' English proficiency. This study involved 126 participants from Bantaan Peninsula University and examined that the implementation of English Discoveries is an effective media to improve students' English Proficiency.

\section{METHODOLOGY}

\section{Research Design}

This study conducted by using Qualitative research. Qualitative research is a scientific method of observation to gather non-numerical data. This research answers why and how a certain phenomenon may occur rather than how often. This study will take the actual data from students of English intensive program and lecturer of English intensive program who use English Discoveries for English intensive program without many manipulations in order to get the data more deeply.

\section{Setting and Subject of the study}

The data will be collected in Islamic University of Sunan Ampel Surabaya and the subjects that will be focused on are all of the English Teachers and the students who implementing the blended learning approach using English Discoveries as their Learning Management System.

\section{Data and Source Data}

The data will be collected to answer those research questions such as what are the students' and teachers' perception of the use of English discoveries in English intensive program at Uin Sunan Ampel Surabaya and what are the challenges faced by the teachers and students when using English discoveries in English intensive program at Uin Sunan Ampel Surabaya. Furthermore, the source data are from students and teachers. Those research questions will be collected by interview.

\section{Data Collection technique and Instrument}

To collect those research questions, the data will be collected by doing the interview. The purpose of the interview is to get the information deeply from the interviewee. The participants who will be interviewed are 16 students from different faculties and 6 English teachers who use English Discoveries in English intensive program at Uin Sunan Ampel Suarabaya. The 16 students consist of:

\section{FINDINGS AND DISCUSSION}

\section{A. Students' Perceptions of English Discoveries}

\section{a. The Definition of English Discoveries}

The result from the first question in Interview between the researchers and the participant showed that all of the participants assumed that English Discoveries is the web application which is used by students in Learning English. This is the application that provides the materials for the students. There are many task there and the students must be doing the task in every week, there will be the deadline in ever task. Moreover, this application has several features that can be used to learn English especially in basic skills such as listening, reading, speaking, writing, grammar and etc. "I like this application, because it has several features that made me enthusiastic to learn" said one of the students from Tarbiyah faculty.

\section{b. The Implementation of English Discoveries}

Overall the participants already understood about the use of English Discoveries well, how they applied it from the beginning to open the web, open every material prepared by the system, worked on the tasks and activities available and how and when they work on the final examination in online. One the expressing students from Economic faculty "how to operate it is easy, because we only search in Google. We can also download it in our mobile phone"

\section{c. The Challenges of English Discoveries}

The challenges that faced by the participants from the result of Interview between the researchers and the participants are quite similar in the Technical Problem such as when they do not 
have good Internet connection. English Discoveries is the online Learning Management System that to operate it we need Internet connection but sometimes, the participants faced the problem with their Internet connection. Besides that, 4 from 16 participants stated that other challenges that they face when they are doing record in their speaking activity sometimes the system does not work well and the system does not catch their voice when they do record. "Little bit difficult when we do voice recording. So, sometimes this can be a waste of time" said one student from science and technology faculty.

\section{d. The Benefit from English Discoveries}

The benefit from the use of English Discoveries has felt by 10 from 16 participants. It is proven by the improvement between the participants' middle test and their Final Examination score. The use of this Learning Management system is also Improve the students' English Skill, for example in their Speaking skill they directly learn from the native speakers. Moreover, they will get new vocabulary through Reading activity. It means that if they do not understand about the meaning of the difficult word they directly could check it in the system. "From English discoveries, I can improve my English skills" said one student from Dakwah faculty

\section{B. Teacher perception of English Discoveries}

\section{a. The Teachers impression of English}

\section{discoveries}

From the first question in interview the participant assumed that by using English discoveries is beneficial for them in their teaching process. The participant as a teacher happy to use this application because using English discovery helps them give the material for the students in class and outside the class. Moreover English discovery can help the teacher to submit the assignment by online and do not need to face each other. But to say that, the participant stated that 5 of 6 participants still confused to use the English discovery, one that expressing view that "actually English discoveries is beneficial in English intensive program. However there are some teachers still confuse to use it, because, this is the new that used in English intensive program". Then they also assumed that the activity of the English discovery is bored which means that the materials are the same in every week "sometimes the material in English Discoveries made the students' bored, because the material in every week almost the same" said one English teacher.

\section{b. Advantages and disadvantages of English}

\section{Discoveries}

From the second question in interview the participants stated there are many varieties in practice English skill such as speaking, listening, writing and reading. The participant can take the material from the English discovery then developing by their own ways in order to adjust with the students' need. Beside of the advantages, there are also the disadvantages that faced by the participant when used English discovery at the time. For the example, the exam that presented was not appropriate with the level of the students. "Sometimes students feel difficult when doing the test, because the questions that were given not appropriate with their level" said one English teacher

\section{c. The Challenges faced by teacher}

The challenges that faced by the participants are they always remain the students to do the assignment before the deadline, because they assume that the student will not do the assignment if they do not remain them. On the other hand, the challenge is about the internet connection, because the users should have a good connection when using the English discoveries. One that expressing view "it is the online system. So, we should have a good internet connection while using English discoveries"

\section{Discussion}

\section{a. Students Perception}

Based on the findings showed that almost of the participants stated if they know the implementation of English Discoveries well. It is proven that they can operate it even though there are several challenges that they faced. Moreover, almost of the students also feel the benefits from the implementation of this Learning Management System in their English Skill, and also their score although the benefit does not felt by the participants.

\section{b. Teacher perception}

According to the finding, the researcher gets the data about the perception about English discovery learning from the teacher. The teacher perception said that English discovery has several advantages which mean that this application is beneficial to help the teacher in teaching English. However, there are also some disadvantages and challenges when use this application. 


\section{CONCLUSION}

The result of the study between the teachers and the students' perceptions literally showed that the Implementation of English Discoveries is the good thing, because they feel some beneficial things when they Implement it, besides the benefits there are several weaknesses too related in the implementation of this Learning Management Systems, it is normal because this is the new thing for the Participants.

Having the result of the study, the researcher suggested to the Institutions who implement this Learning Management System to recognize their students' ability and also all the possibilities that will happened during the Implementation and also the teachers should be training more about how to use this. Moreover, it is also suggested to the students to utilize this system as much as they can because there are many features that very useful for them.

\section{REFERENCES}

[1] Lynn, J. M. (2014). Blended Learning: How Teachers Balance the Blend of Online and Classroom Components. Journal of Information Technology Education , 121-140.

[2] Sherilyn, Y. (2018). Assessment and Evaluation of Bpsu English Discovery Online. International Journal of Science and Research, 55 58.

[3] Sudarman. (2018). Pengaruh strategy pembelajaran blended learning terhadap perolehan belajar konsep dan prosedur pada mahasiswa yang memiliki self-regulated learning berbeda. Research Gate, 107-117.

[4] Vijay, E. (2012). English Discoveries Online (EDO): Examining Learner-Instructor Interaction: A Case Study at Hanoi Univeristy, Vietnam. Research Gate , 1-12. 